\title{
医療事故防止におけるヒューマンファクターによる インシデントと個人特性の関係分析
}

天 野寛

愛知新城大谷大学社会福祉学部
酒 井 俊 彰

名城大学大学院都市情報学研究科
酒 井 順 哉

名城大学大学院都市情報学研究科

近年, 医療事故防止の研究において, 組織の改善だけでなく医療スタッフ個々人の特性に応じた安全対策 のサポート体制の研究も必要になってきた。本研究の目的は, インシデントレポートと心理検查を組み合わ せることによって，インシデントと関連する個人特性を探ることにある。方法は，エゴグラムと POMS を用 い，それがインシデントにどのように関係しているのか，2 施設の看護師計 790 名を対象に，インシデント レポートから H 群（高リスク群）とL群（低リスク群）を抽出して 2 つの理検査との関係を分析した。結 果は，エゴグラムの AC および POMS の T-A， D， A-H，Cについて H 群の值が L 群よりあ高く，それぞれ 有意な差が認められた。このように, 緊張感や不安感が高く, 過剩適応の傾向のある者は, 自己表現を円滑 におこなうことが医療事故の予防に効果のあることが示唆された。

キーワード：リスクマネジメント，パーソンアプローチ，インシデントレポート，医療ミス

\section{問 題}

医療事故の予防には，ヒューマンェラーの観点 とシステムアプローチ (System Approach) への取 り組みが不可欠であり, 組織的な環境整備の必要 性が提言されている (Leape, Bates, Cullen, Cooper, Demonaco, Gallivan, Halliey, Ives, Laird, \& Laftel, 1995)。1999 年に出版された米国 IOM 報告書「To err is human」の影響で医療安全についての関心 が高まりをみせたことは記憶に新しく，システム アプローチの必要性を改めて知らしめる結果と なった (Institute of Medicine, 1999)。そして現在, 組織的なチェック体制による医療事故の再発防止 への取り組みは, 多くの病院で実践され一定の効 果を上げている。このシステムアプローチと同様 に医療事故防止対策にはむう一つの重要なアプ ローチがある。それは，医療ス夕ッフ個々人の性 格特性に基づいたエラーの防止策を考える方法,
すなわちパーソンアプローチ (Person Approach) である。事故防止対策にはこれら両面のアプロー チで対応する必要がある (Reason, 2000)。また, 近年，同じような事故を繰り返す医療スタッフ， すなわちリピーターの存在む明らかになってきた。 このため, パーソンアプローチの研究において, 職員の意識改革だけでなく，医療スタッフ個々人 の特性に応じた安全対策のサポート体制も必要に なってきた。本研究の目的は, そうした医療現場 の傾向をもとに，個人差要因に着目し，それらが 医療事故とどのように結びついているのか, イン シデントとの関連が推測される個人特性を探るこ とである。

「To err is human」が提出された当時, その報告 書に対する批判がおこなわれた。報告書では，工 ラーの発生率の大幅な減少を要求しているが, 医 療に打けるエラーの発生率がほとんど把握されて いない状況では, その要求の実現は困難であると 
の指摘であった (Brennan, 2000)。その影響を受け て, 日本の医療機関においても，インシデントレ ポートを活用する研究がおこなわれるようになっ た。医療界では「危うく事故になりかけたが事故 には至らなかった出来事」をインシデントやニア ミスという。また，その際ひやりとした，はっと したという感覚を伴うので，ヒヤリ・ハットの事 例と呼ばれることもある。最近は米国医療機関の インシデントの概念を参考に, アクシデントを医 療ミス, ニアミスをヒヤリ・八ットとして, 総称 してインシデントと呼ぶことが多い。アクシデン トを防ぐには，その奥に無数にあるヒヤリ・ハッ 卜に対する対策が必要となる。重大な事故に発展 したものも，ヒヤリ・ハットにとどまったものも， その原因には共通部分が多いので, 発生頻度の高 いヒヤリ・ハットの事例を調査して, その発生要 因などを解明することが重要であるといわれてい る（山内・山内, 2001）。現在, インシデントレ ポートの詳細な分析によってェラーの発生率は把 握され, システムの改善を提案する方法が模索さ れている(岡崎, 2000)。さらに, インシデント レポートと背景要因との関係分析など様々な手法 が試みられ, 事故防止に対する取り組みが検討さ れてきている（藤田，2003）。また，ヒューマン エラーの視点から医療ミスの予防に対する考察も おこなわている（天野・酒井, 2004)。そこで, 本 研究では, パーソンアプローチの観点から, イン シデントレポートと心理検査を組み合わせること によって, インシデントと関連する個人特性を探 ることを試みた。それにより, 医療スタッフの個 人特性を考慮した現場への効果的なフィードバッ クについて検討した。

\section{方 法}

調査対象一般病床数 450 床の総合病院 (A 病 院）に勤務する看護師 270 名（年齢：20歳未満 4 名, 20 歳以上 30 歳未満 157 名, 30 歳以上 40 歳未満 44 名, 40 歳以上 50 歳未満 43 名, 50 歳以
上 19 名, 未回答 3 名。勤務年数： 1 年未満 50 名, 1 年以上 2 年未満 49 名, 2 年以上 4 年未満 49 名, 4 年以上 10 年未満 83 名, 10 年以上 34 名, 未回 答 5 名）と一般病床数 660 床の総合病院（B 病 院）に勤務する看護師 520 名（年齢：20歳未満 4 名, 20 歳以上 30 歳未満 278 名, 30 歳以上 40 歳未満 104 名, 40 歳以上 50 歳未満 89 名, 50 歳 以上 41 名, 未回答 4 名。勤務年数： 1 年未満 56 名, 1 年以上 2 年未満 66 名, 2 年以上 4 年未満 71 名, 4 年以上 10 年未満 138 名, 10 年以上 188 名, 未回答 1 名) の総計 790 名。

調查期日 $\mathrm{A}$ 病院は平成 16 年 2 月, $\mathrm{B}$ 病院は 平成 16 年 7 月に調查を実施した。

手続き 病院に勤務する看護スタッフを対象に, 質問紙によって, 個人特性とインシデント（医療 ミスとヒヤリ・ハット）の発生率を調査した。調 査は, 看護部長および看護部リスクマネジメント のメンバーの協力で各所属長の指示のもと実施さ れた。

調査用紙の構成: 調查用紙の構成は次の通り である。1) インシデント（体験回数・発生理由） について。2) 心理検査（エゴグラム, POMS）に ついて。

インシデントの設問については,「自身が当事 者だったとき」と「現場に立ち会ったとき」に分 け，それぞれ同じ設問を用意した。診療の業務場 面，すなわちインシデント体験の発生業務場面お よびチェックシートは,「患者に役立つ医療安全 チェックガイド」(酒井, 2003) と「リスクマネ ジメントの基礎と実例」（藤井・小島, 2002）を 参考にした。すなわち，「1．問診・診察」，「2. 採血」, 「3. 臨床検査」, 「4. 放射線 (検査・治療 $)\rfloor$, $\lceil 5$. 与薬」, 「6. 注射」, 「7. 点滴」, 「8. 輸血」, 「9. 麻酔」, 「10. 手術」, 「11. 入院（療養上の世 話)」として 11 の場面に分類され, 業務場面ごと に「体験の有無」と「体験の回数（体験がない場 合は 0 と記入)」が記入された。さらに，それぞ れの発生業務場面について, 患者への影響レベル 
別に件数が記入された。患者への影響レベル別の インシデントとは，ヒヤリ・ハットから重大なミ スまでを段階的に分類したものである。患者への 影響レベルの分類は, 「医療の安全をめざして— 医療安全対策マニュアル—」（医療安全対策委 員会，2002）扎よび「医療安全推進総合対策」 （厚生労働省医療安全対策検討会議，2002）を参 考に，一般的な 6 段階の分類を採用した。影響レ ベルの低い順から「1. 不適切行為があったがそ れが患者には影響しなかった場合」，「2．不適切 行為があったが，患者に実害はなかった場合」, 「3. 事故により傷害が発生し, 観察強化や検査を 必要とした場合」，「4. 事故により傷害が発生し, 治療を必要とした場合」,「5. 事故により傷害が 発生し，後遺症が残った場合」，「6. 事故により 患者が死亡した場合」の6 段階である。

個人特性の測定についてはエゴグラムを用いた。 医療関係では TEG（東大式エゴグラム）の使用頻 度が高いが，医療スタッフを対象に特化したもの は現時点で確認できなかった。そこで，質問項目 が 50 問である杉田版エゴグラムチェックリスト （杉田，1979）を参考に，医療スタッフ版チェッ クリストの作成に取り組んだ。医療スタッフ版エ ゴグラムチェックリストは, 臨床の現場に従事す る看護師数名の協力を得て項目を作成した（項目 は付録に記す)。また，質問紙法により気分状態 を把握するための検査である POMS (Profile of Mood States) を取り入れた。POMS 日本版の質問 項目および選択肢は原文のまま使用した。両検査 の選定は以下のプロセスでなされた。

心理検査の選定 エラー行動とパーソナリティ との関係については, 産業心理学の分野からは 「安全性格診断システム」などが考案されており, エラー行動と性格特性との関連が検討されている （正田，1992）。また，職務満足感とストレスマネ ジメントの観点から，職場ストレッサーによるス トレス反応に影響を与える要因として, ソーシャ ルサポート・タイプ A 行動パターン (Caplan,
Cobb, French, Harrison, \& Pinneau, 1975) が提案さ れている。また，ヒューマンエラーのタイプ分類 からは，ボケ型エラーとドジ型エラーを分類し， どのタイプに該当するか，エラーの起こしやすさ をみる簡単なチェック項目が作られている（芳賀, 2000)。それらを参考に，ここではインシデントレ ポートと個人特性との関係の把握のために, 様々 なテストの候補の中から, 使用頻度と信頼性の観 点より, Y-G 性格検査, $16 \mathrm{PF}$ 人格検査, エゴグ ラム等を候補に挙げた。予備調査の結果, 医療又 タッフを対象にしたエラー行動との関連性につい て，Y-G 性格検查では相関が得られなかった。ま た，16PF人格検查については，キャッテルの性格 検査の特徵であある知能に関する因子が含まれて おり, 技能や知識の側面からエラー行動の指標と して活用が期待された（中野，1993）。しかし，項 目数が 187 問と多く, 多忙な医療スタッフへのア ンケートの中に差し込むには不適切であった。結 局, 医療界で使用頻度の高いエゴグラムと POMS の両テストの使用を決定した。エゴグラムは, 交 流分析から生まれた自我状態を把握するための質 問紙形式のテストである（杉田，1979）。自我状 態とは, 「感情の体系であり，それに関連した行 動パターンを伴っているもの」(Berne, 1970) と定 義されている。現在では, 自己分析をおこなう道 具として医療界のみならず航空界や鉄道界でも社 員研修の中で頻繁に使用されている。本研究では, エゴグラムに見られる個人特性とインシデントレ ポートとの関連性を検討する。また, POMS は気 分を評価する質問紙テストで, 一時的な気分, 感 情の性質を測定できるという特徵を有している。 質問では，過去 1 週間の気分について尋ねている が，それは開発者の McNair らによれば，対象者 のある生活場面における典型的かつ持続的な気分 を表すのに適した長さであるとされている（横 山・荒記，2000）。POMS に見られる気分状態とイ ンシデントレポートとの関連性を検討することで, エゴグラムによる検討結果をさらに補うことがで 
きればと考えて選定した。

調査に対する配慮 調査目的と意義について, 該当する病院の院長に説明し，当該病院のゼネラ ルリスクマネージャの同意を得て協力を依頼した。 調査結果は「結果報告書」としてまとめ, 実施し た病院にリスクマネジメントの資料としてフィー ドバックした。また，個人特性を考慮したフィー ドバックの資料の提供を実施するため, 本研究で は回答用紙に対してハンドルネームの使用を設定 した。このパスワードの使用により，個人情報を 保護しつつ, 自己の回答結果と問題点を照会する ことが可能となった。この個人資料は, 医療ス タッフ全体の中で，自分がどのあたりに位置する のか等, 自己点検を抢こなうあのであり，これか らの安全な診療業務を㧍こなうための自己認知を 深める資料として活用されることを目的としてい る。さらに，自己変容が可能な方法沶よび個人面 談が可能なサポートシステムを提供し, 結果閲覧 から，意欲の低下が起きないょうに配慮した。

\section{結 果}

\section{インシデントの分析}

Figure 1 は, A 病院と B 病院を合わせた過去 1 年間の業務場面からみたインシデント発生の看護 師一人当たりの件数である。体験の回数について は, インシデントレポート作成ソフトを一度閲覧
しそそれをとに記入された。A病院（450床） では総件数 729 件, B 病院（660 床）では総件数 1397 件の結果が得られた。藤田 (2003) の研究で は, 年間約 1400 件のインシデントを対象にして いるが，それは病床数約 900 床の病院の資料であ る。

インシデントは, 自分が起こしたものか, ある いは目撃したものかを比較するため，「自身が当 事者だったとき」と「現場に立ち会ったとき」と に分類して示してある。結果は，「与薬」抽び 「入院」についてのインシデント体験の件数が顕 著に高く，次に「点滴」，「注射」そして「採血」 の順で体験数が高く示されている。また，「自身 が当事者だったとき」と「現場に立ち会ったとき」 すなわち目撃した件数との間に顕著な差はみられ なかった。

次に, 患者への影響レベル別のインシデントが, それぞれどの程度発生しているのかを探った。Figure 2 は，発生業務場面全体を合計した場合での A 病院と B 病院を合わせた患者への影響レベル別イ ンシデントの看護師一人当たりの発生件数を示し ている。Figure 1 の業務場面からみたインシデン 卜発生の件数と同じく,「自身が当事者だったと き」と「現場に立ち会ったとき」に分類して示し てある。結果は, 「不適切行為があったが, 患者 に実害はなかった」の患者への影響レベルの発生

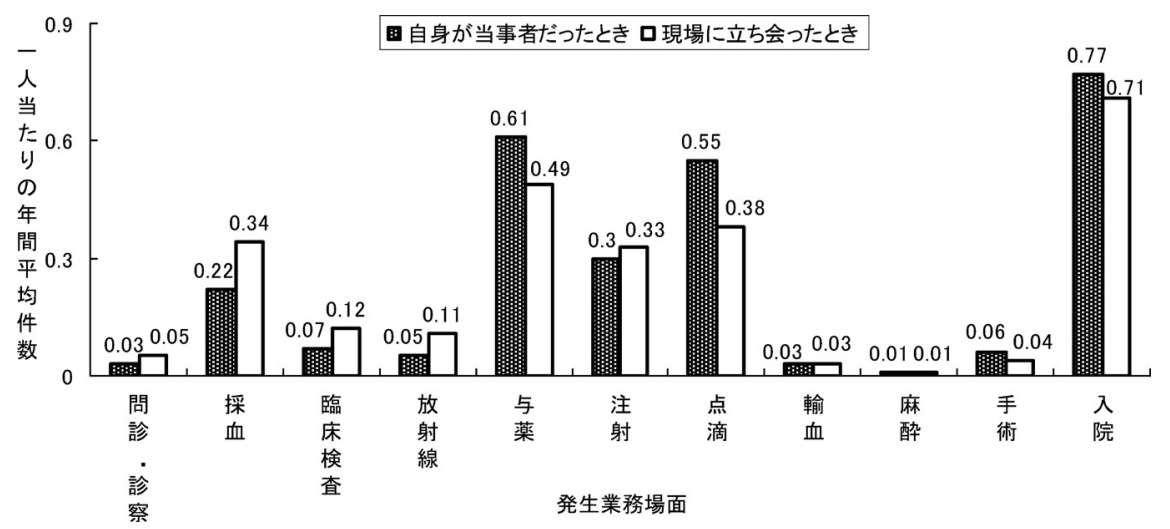

Figure 1 業務場面からみたインシデント発生の一人当たりの年間平均件数 


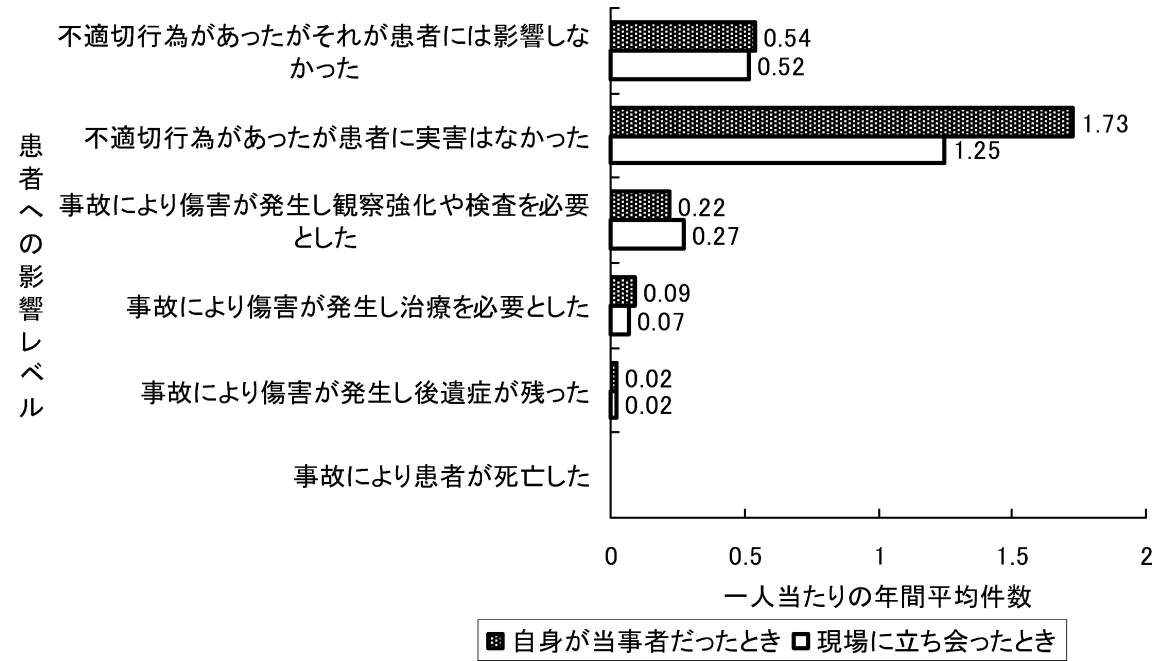

Figure 2 患者への影響レベル別インシデント発生件数

頻度が顕著に高かった。

$\mathrm{H}$ 群（高リスク群）の抽出

インシデントの発生件数について, 発生件数の 高い群と低い群の分類を試みた。「発生業務場面」 すべてについて，「自身が当事者であったとき」に おけるインシデント発生件数に関して，平均值に $1 \mathrm{SD}$ を加算した得点以上（より大きい得点）の者 を高得点群（高リスクの群；H群とする）とし た。A病院 B 病院ともに大きな違いは見られな かった。両病院を合算した結果， $\mathrm{H}$ 群は, インシ デントの件数が 6 回以上（H 群>インシデントの 平均 2.69 件 $+S D$ 2.85）の群で 790 名中 105 名で あった（インシデントの最大值は 20 件で 2 名，最 小值は 0 件で 166 名。中央值は 2 件）であった。 次に, $\mathrm{H}$ 群の特徵を際立たせるために低リスクの 群を比較対照群として L 群を設定した。L 群は, インシデントが 0 件の群である。

\section{エゴグラムと POMS の H 群と L 群の比較}

Figure 3 は, A 病院と B 病院を合わせた場合の $\mathrm{H}$ 群と L 群との関係を比較したエゴグラムについ ての結果である。各自我状態の特徴として,「CP (Critical Parent)：厳しさ・信念をもつ（批判する 自我)」,「NP (Nurturing Parent)：思いやり・世話

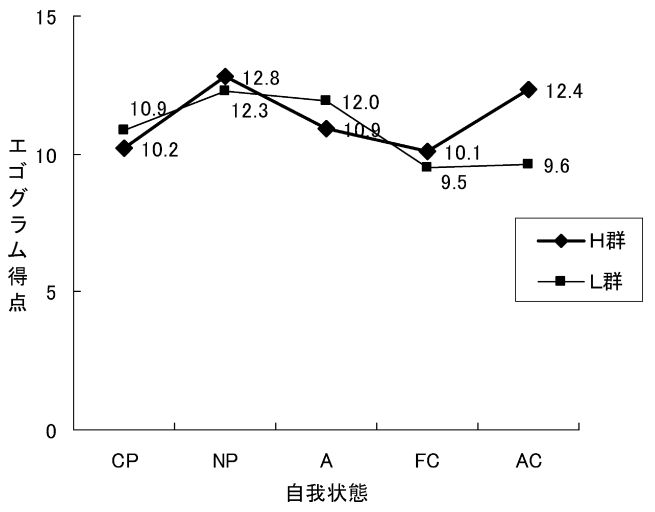

Figure 3 エゴグラムにおける H群と L 群の比較

好き（やさしい自我）」，「A (Adult)：能率的・冷 静 (考える自我)」,「FC (Free Child)：のびのび・ 明るさ (自由な自我)」,「AC (Adapted Child)：従 順・協調的（人に合わせる自我）」と定義されて いる（杉田，1979）。H群そしてL群ともになだ らかな N 型のパターンを示している。杉田版のオ リジナルのエゴグラムでは，一般的に看護師の平 均的パターンは M 型を示すと言われている（杉 田，1985）。このパターンの差は，医療スタッフ 版エゴグラムの FC 值が若干低く表示されるため に生ずるむのと思われる。質問項目を職場環境に 


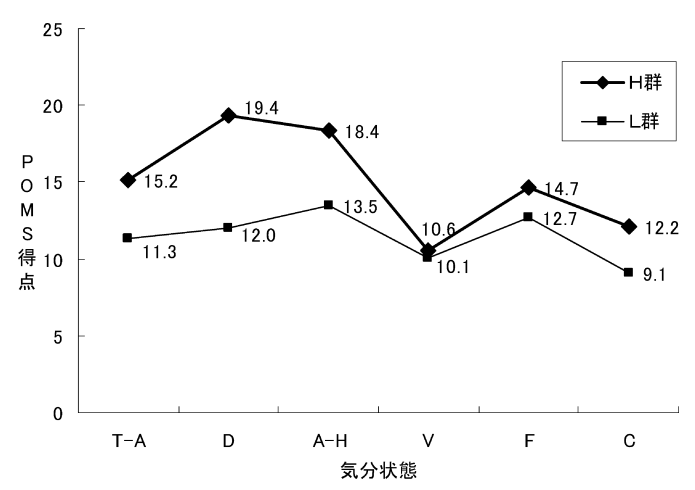

Figure 4 POMS におけるH群とL群の比較

設定したために，日常を設定した質問項目から得 られる結果よりも，環境による抑制の要素が働く ためであると考えられる。

H 群と L 群を比較すると, AC (Adapted Child) の自我状態について有意な差が検出され, $\mathrm{H}$ 群の 方が L 群よりも $\mathrm{AC}$ の值が高いことが確認された (H群 vs L 群 $\mathrm{AC} ： d f=241, t=5.22, p<.01)$ ) AC とは, 協調性, 依存性の自我状態であり, これが 高いと過剩適応といわれ, 自己主張ができず, 自 我の葛藤状態を招きやすいと考えられている。

POMS は「T-A (Tension-Anxiety)：緊張・不安 感」, 「D (Depression-Dejection): 抑うつ感・自信 喪失感」,「A-H (Anger-Hostility): 不機嫌・イラ イラ」, 「V (Vigor): 活力」, 「F (Fatigue): 疲労感」, $\lceil\mathrm{C}$ (Confusion): 思考障害」の 6 つの尺度からな る。Vは他の 5 つの尺度とは負の相関にあり, こ の得点低下は, 活気が失われていることを示唆す る。

Figure 4 は, A 病院と B 病院を合わせた場合の $\mathrm{H}$ 群とL 群との関係を比較したPOMS についての 結果である。エゴグラムと同様に, H 群と L 群で 差の検定を抢こなうと, 両病院について, T-A, D，そして A-H の 3 つの尺度に打いてそれぞれ有 意な差が認められ，H群の方が高く示された。 T-A については, この值が高いほど緊張感や不安 感が強いことを示している。Dについては，この 值が高いほど抑うつ感や自信喪失感が強いことを
示している。A-H については, この值が高いほど 不機嫌でイライラしている状態が強いことを示し ている。すなわち, 気分的側面として, H 群は $\mathrm{L}$ 群に比べて緊張・不安感が高く, 抑うつ的な傾向 が認められることが示唆された（H群と L 群の差 は, T-A : $d f=189, t=4.1, \quad p<.01, \quad \mathrm{D}: d f=172$, $t=4.48, \quad p<.01, \quad \mathrm{~A}-\mathrm{H}: d f=184, \quad t=4.15, \quad p<.01$ であった)。

\section{考察}

インシデントの発生件数から医療事故を起こし やすい群（H群：インシデントが 6 回以上の群。 高リスク群）とそうでない群（L群：回数が 0 の 群。低リスク群）を抽出し，エゴグラムと POMS を用いてインシデントと個人特性の関連を探った。 その結果, 医療スタッフ版エゴグラムの $\mathrm{AC}$ 抢よ び POMS の T-A，D，A-H について有意な差がみ られた。 $\mathrm{AC}$ は「従順, 協調的」な自我状態で, それが高いと過剩適応の傾向があるとされている。 本調査で使用した項目を見ると，「カンファレン スなどで思ったことが言えずあとで後悔すること がある」,「自分の能力に限界を感じるなど劣等感 にさいなまれることがある」，「ふだん患者におだ やかに接しているが怒りが込み上げるときがある」 などである。すなわち, H 群はネガティブな感情 が生じたときに，それを適切に表現できない特性 を持っていることがインシデントの頻度に影響し ている可能性が考えられる。POMS 質問紙では, 過去 1 週間のあいだの気分状態を書き込むことを 教示しているが, POMS のマニュアルにあるよう に, 検査結果は典型的, 持続的な気分状態を反映 しているとみなすことができる。そのため，年間 を通じてその差はインシデントの件数（1 年間の インシデント件数）の差に表れるのではないかと 仮定した。H群は, 緊張感や不安感, 抑うつ感あ るいは不機嫌などのネガティブな感情状態に陥り やすく, そのような感情を適切に表現できないこ とが示唆される。したがって, インシデントを引 
き起こす要因の一つとして，こうしたネガティブ な感情の不適切な行動化が考えられるのではない か。

以上のように, $\mathrm{H}$ 群ではネガティブな感情を適 切に表現できない傾向が示されたことで，インシ デントの抑制に役立つものとして，スタッフ間の 円滑なコミュニケーションが大切であることが確 認された。 $\mathrm{AC}$ が高く，自己表現することが苦手 なスタッフに対しては，自由に自己表現ができる ような職場環境を作っていくことが医療事故の予 防につながるものと思われる。

\section{引用文献}

天野 寛・酒井順哉 (2004)。医療事故防止に打ける医 療スタッフの安全意識に関する研究 医療情報学, 24(6), 639-655.

Brennan, T. A. (2000). The Institute of Medicine report on medical errors. Could it do harm? New England Journal of Medicine, 342, 1123-1125.

Caplan, R. D., Cobb, S., French, J. R. P., Harrison, R. V., \& Pinneau, S. R. (1975). Job demands and worker health. National Institute for Occupational Safety and Health. Cincinatti.

Berne, E. (1970). Games People Play. The basic handbook of transactional analysis. New York: Ballantine Books..

藤井清孝・小島恭子 (2002)。いまから学ぶ リスクマ ネジメントの基礎と実例 ミクス

藤田 茂 (2003)。心身分析による看護職員の忙しさと
ヒューマンエラーの関係 看護管理, 13, 120-123.

芳賀 繁 (2000). 失敗のメカニズム 日本出版サービ ス

Institute of Medicine (1999). To err is human. Building of a safer health system. Washington, DC: National Academy Press

医療安全対策委員会 (2000). 医療の安全をめざし て一医療安全対策マニュアル—医療法人 社団 カレスアライアンス

厚生労働省医療安全対策検討会議 (2002). 医療安全推 進総合対策 — 医療事故を未然に防止するために— じほう

Leape, L. L., Bates, D. W., Cullen, D. J., Cooper, J., Demonaco, H. J., Gallivan, T., Halliey, R., Ives, J., Laird, N., \& Laftel, G. (1995). Systems analysis of adverse drug events. Journal of American Medical Assoication, 274, 35-43.

中野敬子 (1993). 精神身体的健康におけるハッスルと 人格特性の役割 心理学研究, 64(2), 123-127.

岡崎 董 (2000). リスクマネジメントの新たな取り組 みについて 日本手術医学会誌，51, 54 .

Reason, J. (2000). Human error: Models and management. British Medical Journal, 320, 768-770.

酒井順哉 (2003). 患者に役立つ医療安全チェックガイ ド作成の試み医学のあゆみ，204(11), 804-806.

正田 亘 (1992). 産業・組織心理学. 恒星社厚生閣

杉田峰康 (1979). 新しいエゴグラム・チェック・リス 卜 (ECL) について 交流分析研究，4(1), 28-40.

杉田峰康 (1985)。講座サイコセラピー8 交流分析 日 本文化科学社

山内佳子・山内隆久 (2001). 医療事故 朝日新聞社

横山和仁 - 荒記俊一 (2000). 日本版 POMS 手引 金 子書房

- 2005.11.11 受稿, 2007.1.5 受理一

\title{
Analysis of the Relationship between Incidents Caused by Human Factors and Attributes of Individuals to Prevent Medical Accidents
}

\author{
Hiroshi AMANO ${ }^{1}$, Toshiaki SAKAI ${ }^{2}$ and Junya SAKAI ${ }^{2}$ \\ ${ }^{1}$ Faculty of Social Welfare, Aichi Sinshiro Otani University \\ ${ }^{2}$ Graduate School of Urban Science, Meijo University
}

The Japanese Journal of Personality 2007, Vol. 16, No. 1, 92-99

It has become increasingly necessary to look into safety-measure supporting systems that take characteristic traits of individual medical staff into consideration, in addition to organizational improvement, in recent years in the study to prevent medical accidents. This study attempted to link incident reports and psychological tests in order to explore such individual traits that may be related to incidents. High and low risk groups were extracted from incident reports, and Egogram and POMS scores were analyzed for 790 registered nurses at two facilities. Scores were significantly higher for high than low risk group in AC of Egogram, as well as T-A, D, A-H and C of POMS. The result suggested that smooth self-expression would be effective in preventing medical accidents for those who felt greater tension and anxiety, and for those with high AC propensity as well.

Key words: risk management, person approach, incident report, medical errors 


\section{付 録}

医療スタッフ版エゴグラムのチェックリストの内容は以下の通りである。

\section{CP (Critical Parent) に該当する項目 :}

1) 院内の業務などルールを守ることに厳しいほうである。

2) 同僚や部下のミスをなかなか許すことができないほう である。

3）患者に対してときどき説教するような口調になること がある。

4）就業規則など馴れ合いやルーズなことは嫌いである。

5）管理や点検などきちんとチェックしないと気がすまな いほうである。

6）業務上のささいなミスでもうやむやにすることは嫌い である。

7）職場ではとくに自分は責任感の強い人間だと思う。

8）上司や先輩に対しても間違っていると思えば意見する。

9）患者に「だめでしょ」「してはいけないですょ」という 言い方をする。

10) カンファレンスでは自分の考えをはっきり主張すべき だと思う。

\section{NP (Nurturing Parent) に該当する項目：}

11）同僚がミスをしたときついかばってしまう。

12）患者に限らず他人の世話をするのは好きなほうである。

13）患者から質問を受けたとき出来る限り時間を作って応 えようとする。

14）治療上好ましくないとされていても患者の希望をかな えることがある。

15）患者に助けを求められるとなんとかしてあげたいと思 う。

16）自分は患者に対して思いやりのあるほうだと思う。

17）患者の容態が悪くなるとなんとか元気付けてあげたい と思う。

18）スタッフのミスは問題がなければ責めないで許してあ げる。

19）患者の気持ちを考えて禁止の「つけ届け」を受け取る こともある。

20)同僚にプレゼントしたり奢ったりすることが好きであ る。

\section{A (Adult) に該当する項目 :}

21）教育や研修の場には積極的に参加している。

22）患者への説明が事務的になりすぎることがある。

23）不稳の患者に対しても冷静に対応することができる。

24）インフォームドコンセントは患者とのトラブルを防ぐ ために必要だ。

25) 仕事は能率的にテキパキと片付けていくほうである。

26）他職種のスタッフの意見を参考にすることが多い。
27）勤務上の手落ちがないよう行動計画表を作成し実行し ている。

28）医療機器・医薬品などのマニュアルはきちんと読んで いるほうである。

29）セカンドオピニオンが必要なシステムかどうか考えた ことがある。

30) 不安な箇所があれば常に教科書などで自分の知識を確 認している。

FC (Free Child) に該当する項目 :

31) 気の合うスタッフとよく飲みに行ったりカラオケに行っ たりする。

32）子供と接するのが好きなほうである。

33）患者と冗談を言い合ったり親しくなるのが早い。

34）プライベートではよく遊びに出かけるほうである。

35）スタッフの前で言いたいことを遠慮なく言う。

36）自分は患者に人気があるほうだと思う。

37）うれしい時や悲しい時に顔や動作に自由に表すことが できる。

38）患者やその家族に対して必要以上に興味をもってしま う。

39）皆とさわいだりはしゃいだりするのが好きなほうであ る。

40) 職場の中でも目立つことが好きなほうである。

AC (Adapted Child) に該当する項目 :

41) カンファレンスなどで思ったことが言えずあとで後悔 することがある。

42）スタッフから良く思われようと振る舞うようなところ がある。

43）感情的にたかぶっている患者をみるとこちらが動摇し てしまう。

44）自分の能力に限界を感じるなど劣等感にさいなまれる ことがある。

45）患者や家族から自分がどう思われているのか気にする ほうである。

46）ふだん患者におだやかに接しているが怒りが込み上げ るときがある。

47）自分は上司や先輩の言うことに影響されやすいと思う。

48）遠慮がちで消極的なほうである。

49）イヤなことをイヤと言わずにおさえてしまうことが多 い。

50) 内心では不満だが表面では満足しているように振る舞 う。 